\title{
EL TRIBUNAL CONSTITUCIONAL AVALA LA LEY ORGÁNICA DE PROTECCIÓN DE LA SEGURIDAD CIUDADANA ("LEY MORDAZA"): COMENTARIO DE LA STC 172/2020, DE 19 DE NOVIEMBRE
} THE CONSTITUTIONAL COURT APPROVES THE ORGANIC LAW ON THE PROTECTION OF CITIZEN SECURITY (“GAG LAW"): COMMENT ON STC 172/2020, OF NOVEMBER 19TH

\author{
Ana Aba Catoira \\ Universidade da Coruña
}

Cómo citar / Nola aipatu: Aba Catoira, A. (2021). El Tribunal Constitucional avala la Ley Orgánica de Protección de la Seguridad Ciudadana ("ley mordaza”): comentario de la STC 172/2020, de 19 de noviembre. Legebiltzarreko Aldizkaria - LEGAL - Revista del Parlamento Vasco, 2: 172-189

https://doi.org/10.47984/legal.2021.005

\section{RESUMEN}

En su Sentencia 172/2020, de 19 de noviembre (Recurso de Inconstitucionalidad 2896-2015 presentado por 97 diputados del PSOE; 11 de Izquierda Plural y Chunta Aragonesista; 4 de Unión Progreso y Democracia y 2 del Grupo Mixto del Congreso de los Diputados, impugnando los arts. $19.2^{\circ}, 20.2^{\circ}, 36,2^{\circ}$ y $23^{\circ}, 37.1^{\circ}$ en relación con los arts. $30.3^{\circ}, 37.3^{\circ}$ y $7^{\circ}$, así como la disposición final primera de la Ley Orgánica), el Pleno del Tribunal Constitucional ha avalado la constitucionalidad de la Ley Orgánica 4/2015, de 30 de marzo, de Protección de la Seguridad Ciudadana (LOPSC), aprobada por el PP en 2015 y conocida por sus críticos como "ley mordaza". La sentencia del máximo intérprete de la Constitución, de la que ha sido ponente el presidente del Tribunal, Juan José González Rivas, desestima la mayoría de las impugnaciones confirmando su adecuación constitucional, salvo la previsión de la necesidad de autorización para el uso de imágenes o datos de autoridades o miembros de las Fuerzas y Cuerpos de Seguridad del Estado, prevista en el art. $36.23^{\circ}$ de la Ley.

Como a nadie se le oculta, esta resolución tiene especial relevancia porque la LOPSC ha estado, desde su aprobación, en el punto de mira social y político, con el anunciado recurso de inconstitucionalidad que ahora se resuelve. Y, este pronunciamiento del Alto Tribunal, 
que confirma la constitucionalidad de los preceptos impugnados con la excepción de la "autorización", no ha puesto fin a la confrontación de posiciones, pues tampoco ha tenido una acogida pacífica, tal como era de esperar.

\section{PALABRAS CLAVE}

Libertad, seguridad ciudadana, administración, sanción.

\section{ABSTRACT}

In its Sentence 172/2020, of November 19 (Constitutional Challenge 2896-2015 presented by 97 deputies of PSOE; 11 from "Izquierda Plural" and "Chunta Aragonesista"; 4 from "Unión Progreso y Democracia” and 2 from the Mixed Group of the Congress of Deputies, challenging articles $19.2^{\circ}, 20.2^{\circ}, 36.2^{\circ}$ and $23^{\circ}, 37.1^{\circ}$ in relation to articles $30.3^{\circ}, 37.3^{\circ}$ and $7^{\circ}$, as well as the first final provision of the Organic Law), the Plenary of the Constitutional Court has endorsed the constitutionality of Organic Law 4/2015, of March 30, on the Protection of Citizen Security (LOPSC,) approved by the PP in 2015 and known to its critics as "gag law". The Judgment of the highest interpreter of the Constitution, of which the President of the Court, Juan José González Rivas, has been the speaker, dismisses most of the challenges confirming their constitutional adequacy except for the provision of the need for authorization to use images or data of authorities or members of the State Security Forces and Bodies, provided for in art. $36.23^{\circ}$ of the Law. Since it is hidden from anyone, this resolution has special relevance because the LOPSC has been, since its approval, in the social and political spotlight, with the announced appeal of unconstitutionality that is now being resolved. And, this pronouncement of the High Court, which confirms the constitutionality of the contested precepts with the exception of the "authorization", has not put an end to the confrontation of positions, since it has not had a peaceful reception, as expected.

\section{KEYWORDS}

Freedom, citizen security, administration, sanction.

\section{LABURPENA}

Azaroaren 19ko 172/2020 Epaian (2896-2015 konstituzio-kontrakotasuneko errekurtsoa, PSOEko 97 diputatuk aurkeztua; Izquierda Pluraleko eta Chunta Aragonesistako 11 diputatuk; Unión Progreso y Democraciako 4 diputatuk eta Diputatuen Kongresuko Talde Mistoko 2 diputatuk aurkeztua, 19.2.a, 20.2.a, 36.2.a eta 23.a, 37.1.a artikuluen kontra, 30.3.a, 37.3.a eta 7.a artikuluekin lotuta, baita Lege Organikoaren 
azken xedapenetako lehenarekin ere), Konstituzio Auzitegiaren Osoko Bilkurak bermatu egin du Herritarren Segurtasuna Babesteko martxoaren 30eko 4/2015 Lege Organikoaren konstituzionaltasuna, hain zuzen ere, Alderdi Popularrak 2015ean onartutako eta haren kritikariek "mozal-legea" deitzen duten lege organikoarena. Konstituzioaren interprete gorenaren epaiak -Auzitegiko lehendakari Juan José Rivas González txostengile izanik- aurkaratze gehienak ezetsi ditu, legearen egokitasun konstituzionala berretsiz, betiere Estatuko segurtasun-indar eta -kidegoetako kideen edo agintarien irudiak edo datuak erabiltzeko baimenaren beharrari buruzko aurreikuspena izan ezik, Legearen 36.23 artikuluan jasota dagoena.
Ez zaio inori ezkutatzen ebazpen horrek garrantzi berezia duela, izan ere, Herritarren Segurtasuna Babesteko Lege Organikoa gizartearen eta politikaren jomugan egon da onartu zenetik, orain ebazten den konstituzio-kontrakotasuneko errekurtso iragarriarekin. Eta goi-auzitegiaren erabakiak, aurkaratutako manuen konstituzionaltasuna berresten duenak -"baimena" salbuetsita-, ez dio amaiera eman jarreren konfrontazioari, ez baitu harrera baketsua izan, espero zen bezala.

\section{GAKO-HITZAK}

Askatasuna, herritarren segurtasuna, administrazioa, zehapena.

\section{SUMARIO}

I. CONSIDERACIONES GENERALES.

II. LA SEGURIDAD COMO JUSTIFICACIÓN DE POSIBLES RESTRICCIONES DE DERECHOS Y LIBERTADES FUNDAMENTALES.

III. EL RECURSO DE INCONSTITUCIONALIDAD: CUESTIONES CANDENTES. 1. Los registros corporales externos: art. $20.2^{\circ}$ LOPSC. 2. El régimen sancionador previsto en la Ley Orgánica de Protección de la Seguridad Ciudadana. 3. Impugnación del régimen especial para Ceuta y Melilla de rechazo en la frontera de los extranjeros que intenten entrar ilegalmente.

IV. CONCLUSIÓN. 
El análisis que nos ocupa no puede descontextualizarse de la realidad social que se ha conformado en las últimas décadas, donde se han transformado las formas de participación social y política a través del ejercicio de los derechos fundamentales que se dice integran o conforman "el derecho de protesta": el derecho de asociación (art. $22 \mathrm{CE}$ ), el derecho de reunión y manifestación (art. $21 \mathrm{CE}$ ) y las libertades de expresión (art. $20 \mathrm{CE}$ ). Unas nuevas formas de participación social y política que son expresión del ejercicio de derechos fundamentales de especial relevancia que, para un sector de la doctrina y organizaciones de defensa de derechos humanos, se intentan restringir de forma injustificada y desproporcionada a través del régimen sancionador establecido en la LOPSC.

Por otra parte, resulta indicador de la relevancia de la regulación Libertad/Seguridad, recordar que el pasado marzo de 2021, la Comisión de Venecia adoptó, en su 126 sesión plenaria, un dictamen sobre España, donde resalta la conveniencia de reformar la Ley de Seguridad Ciudadana que "debe ir acompañada de una evaluación en profundidad del funcionamiento práctico de la ley y su impacto en los derechos humanos dado su potencial represivo". Las conclusiones a las que llega este órgano consultivo se basan en que la Ley "contiene una serie de disposiciones abiertas que confían a la policía amplios poderes, pero no indican en qué situaciones se pueden utilizar estos poderes, o qué tipo de medidas se pueden tomar. Algunos delitos también están formulados en la ley de manera excesivamente amplia”. En relación con las devoluciones de migrantes en la frontera, Ceuta y Melilla, reconoce que "España se encuentra en una difícil situación de tener que defender sus fronteras y al mismo tiempo cumplir con sus obligaciones en virtud del derecho internacional". Pero, "la ley debe especificar que los agentes de policía no deben proceder con el rechazo en la frontera si, dadas las circunstancias, ven que un extranjero tiene razones convincentes para no utilizar los procedimientos ordinarios de solicitud de asilo".

Pues bien, la Ley recurrida y analizada por el Tribunal Constitucional, establece una serie de medidas de intervención y un régimen sancionador con la finalidad de armonizar la relación entre Libertad/Seguridad. Estos conceptos jurídicos, bienes protegidos en la Constitución, son interpretados por el Pleno del Tribunal Constitucional en la sentencia de referencia, si bien, en el voto particular formulado por la magistrada María Luisa Balaguer Callejón ${ }^{1}$, se sostiene una concepción distinta que difiere totalmente de la mantenida por el Pleno y que califica como "no propia de los estados constitucionales, en los que la reivindicación ante los poderes del Estado, mediante la presión en la calle, se reconoce como forma legítima de expresión

1 Los dos magistrados que votaron en contra de la sentencia fueron María Luisa Balaguer Callejón y Cándido Conde-Pumpido Tourón. 
de la participación política, para la concienciación ciudadana y en el uso del valor constitucional del pluralismo político recogido en el art. 1 CE. Ley de control de la ciudadanía a través de la limitación desproporcionada de derechos para mantener la seguridad".

La problemática jurídica que subyace en esta confrontación entre libertad y seguridad se explica desde la teoría de los límites de los derechos fundamentales para tratar de delimitar hasta dónde alcanzan los poderes limitadores o restrictivos de los derechos y libertades que garantiza nuestra Constitución. Como es sabido, existe una variada tipología de límites: internos o intrínsecos y externos o límites en sentido estricto en tanto que responden a una creación del poder público para proteger los derechos de los demás, el interés general y el orden público. En este orden de cosas, entrarían aquí aquellos límites derivados de la garantía de la seguridad, pues, siguiendo la letra del art. 29 de la Declaración Universal de los Derechos Humanos "en el ejercicio de sus derechos y en el disfrute de sus libertades, toda persona estará solamente sujeta a las limitaciones establecidas por la ley con el único fin de asegurar el reconocimiento y el respeto de los derechos y libertades de los demás, y de satisfacer las justas exigencias de la moral, del orden público y del bienestar general en una sociedad democrática".

Por tanto, la garantía de la seguridad puede justificar la creación de límites de los derechos que, en ningún caso, son categorías absolutas o ilimitadas en una sociedad de convivencia democrática. Ahora bien, ello lo anterior, sin perder de vista que los límites requieren una interpretación y aplicación restrictiva de modo que no se invierta la relación entre la norma -la libertad- y la excepción -la limitación-. Así lo anterior, cuando se ha producido una intromisión en un derecho habrá que analizar su legitimidad, paso a paso, de manera que si la intervención deviene legítima tendrá justificación constitucional. Este análisis descansa en el principio de reserva de ley, reserva jurisdiccional, principio de proporcionalidad (adecuación o idoneidad, necesidad y proporcionalidad en sentido estricto) y garantía del contenido esencial del derecho afectado. Este análisis se ha incorporado en la jurisprudencia constitucional, que viene reiterando que:

\footnotetext{
para comprobar si una medida restrictiva de un derecho fundamental supera el juicio de proporcionalidad, es necesario constatar si cumple los tres requisitos o condiciones siguientes: si tal medida es susceptible de conseguir el objetivo propuesto (juicio de idoneidad); si, además, es necesaria, en el sentido de que no exista otra medida más moderada para la consecución de tal propósito con igual eficacia (juicio de necesidad); y, finalmente, si la misma es ponderada o equilibrada, por derivarse de ella más beneficios o ventajas para el interés general que perjuicios sobre otros bienes o valores en conflicto (juicio de proporcionalidad en sentido estricto) (entre muchas, Sentencia 37/1998, de 17 de marzo, FJ $8^{\circ}$ ).
} 


\section{LA SEGURIDAD COMO JUSTIFICACIÓN DE POSIBLES RESTRICCIONES DE DERECHOS Y LIBERTADES FUNDAMENTALES}

La seguridad ciudadana es una preocupación social y pública de primer nivel y ello llevó a la reforma de la regulación contenida en la Ley Orgánica 1/1992, de 27 de febrero, mediante la aprobación de la Ley Orgánica 4/2015, de 30 de marzo, de Protección de la Seguridad Ciudadana ${ }^{2}$. A mayores, es conveniente recordar que esta ley se acompaña de otras varias que se aprobaron ese mismo año, las dos leyes orgánicas de reforma del Código Penal, que responden a lo que se denomina como expansión del ordenamiento punitivo o sancionador, tanto del Derecho penal como del Derecho administrativo. La reforma legal se justifica, siguiendo la exposición de motivos, por diversos factores: el transcurso del tiempo; los cambios sociales operados en nuestro país; las nuevas formas de poner en riesgo la seguridad y tranquilidad ciudadana; los nuevos contenidos que las demandas sociales incluyen en este concepto; la imperiosa necesidad de actualizar el régimen sancionador; y la conveniencia de incorporar la jurisprudencia constitucional.

Y es en su art. 1 donde establece como objeto legislativo la seguridad ciudadana definida como condición esencial para el pleno ejercicio de los derechos fundamentales y como un bien colectivo. Esta definición imprecisa de la seguridad ciudadana debe interpretarse en sintonía con la doctrina del Tribunal Constitucional que señalaba en la STC 153/2005 que:
la seguridad pública es la actividad dirigida a la protección de personas y bienes y al mantenimiento de la tranquilidad y el orden ciudadano, que incluye un conjunto plural y diversificado de actuaciones, distintas por su naturaleza y contenido, aunque orientadas a una misma finalidad tuitiva del bien jurídico así definido sobre aquello que se considera seguridad ciudadana. Una concepción en plena sintonía con el art. 104 CE que la configura como misión de las Fuerzas y Cuerpos de Seguridad del Estado que aseguran el estado en el cual los ciudadanos gozan de una situación de tranquilidad y estabilidad que les permite ejercer de forma libre y responsable los derechos y las libertades reconocidos constitucionalmente.

Obviamente, la seguridad es un bien jurídico protegido que podrá justificar que determinados derechos puedan verse restringidos en aplicación de medidas de intervención. Ahora bien, deberá hacerse siempre desde la premisa de que la garantía de los derechos fundamentales, en cuanto que elementos estructurales esenciales y fun-

2 Esta ley ha sido reformada puntualmente a través del Real Decreto-ley 14/2019, de 31 de octubre, por el que se adoptan medidas urgentes por razones de seguridad pública en materia de administración digital, contratación del sector público y telecomunicaciones; por el que se da una nueva redacción al apartado 1 del art. 8, relativo al documento nacional de identidad. 
damento del orden político y paz social, integra la seguridad, y de que toda limitación fundamentada en la garantía de la seguridad pública tendrá que superar el juicio de proporcionalidad demostrándose su adecuación, necesidad y proporcionalidad en sentido estricto.

$\mathrm{Y}$ en este sentido debe interpretarse el párrafo $2^{\circ}$ del citado art. 1 , donde se dice que "Esta Ley tiene por objeto la regulación de un conjunto plural y diversificado de actuaciones de distinta naturaleza orientadas a la tutela de la seguridad ciudadana, mediante la protección de personas y bienes y el mantenimiento de la tranquilidad de los ciudadanos". Para dicho fin se regulan acciones preventivas y represivas justificadas por el legislador por "la existencia de una amenaza concreta o de un comportamiento objetivamente peligroso que, razonablemente, sea susceptible de provocar un perjuicio real para la seguridad ciudadana y, en concreto, atentar contra los derechos y libertades individuales y colectivos o alterar el normal funcionamiento de las instituciones públicas" (art. 4.3 LOPSC); intervención previa en aras de lograr la seguridad ciudadana, que es distinta de la posterior actividad sancionadora.

En la adopción de las medidas de intervención, el concepto de seguridad ciudadana ha de interpretarse atendiendo a los fines que persigue la Ley (art. 3) y los principios rectores de la acción de los poderes públicos (art. 4 ), pues la incidencia en el ejercicio de los derechos y libertades ciudadanas ha de reducirse al mínimo posible, en cumplimiento del principio constitucional del favor libertatis o plena efectividad de los derechos fundamentales y libertades públicas, singularmente de los derechos de reunión y manifestación, las libertades de expresión e información, la libertad sindical y el derecho de huelga (art. $4.1^{\circ}$, párrafo segundo, LOPSC). Sin embargo, la ampliación de poderes prevista y la amplitud e inconcreción legislativa nos lleva a afirmar que el listado de los fines contenidos en el art. $3^{3}$, así como de los principios del art. 4, favorecen una interpretación amplia de las intervenciones administrativas

3 El artículo 3 establece los siguientes fines:

“a) La protección del libre ejercicio de los derechos fundamentales y las libertades públicas y los demás derechos reconocidos y amparados por el ordenamiento jurídico;

b) La garantía del normal funcionamiento de las instituciones;

c) La preservación de la seguridad y la convivencia ciudadanas;

d) El respeto a las leyes, a la paz y a la seguridad ciudadana en el ejercicio de los derechos y libertades;

e) La protección de las personas y bienes, con especial atención a los menores y a las personas con discapacidad necesitadas de especial protección;

f) La pacífica utilización de vías y demás bienes demaniales y, en general, espacios destinados al uso y disfrute público;

g) La garantía de las condiciones de normalidad en la prestación de los servicios básicos para la comunidad;

h) La prevención de la comisión de delitos e infracciones administrativas directamente relacionadas con los fines indicados en los párrafos anteriores y la sanción de las de esta naturaleza tipificadas en esta Ley;

i) La transparencia en la actuación de los poderes públicos en materia de seguridad ciudadana". 
en los derechos fundamentales basada en una orientación preventivista de la Ley que, a la postre, fundamentaron el recurso de inconstitucionalidad que esta sentencia resuelve.

\section{EL RECURSO DE INCONSTITUCIONALIDAD: CUESTIONES CANDENTES}

\section{LOS REGISTROS CORPORALES EXTERNOS: ART. 20.2은 LOPSC}

La necesidad de regular los registros corporales resulta evidente a fin de garantizar una mayor protección de los derechos fundamentales que pudieran verse limitados a través de la realización de dichas intervenciones. Una práctica legal necesaria para garantizar la seguridad, pero que ha de estar fundamentada y respetar las garantías básicas guardando el máximo respeto de los derechos fundamentales afectados.

El artículo $20.2^{\circ}$ reza así:

Salvo que exista una situación de urgencia por riesgo grave e inminente para los agentes: a) El registro se realizará por un agente del mismo sexo que la persona sobre la que se practique esta diligencia. b) Y si exigiera dejar a la vista partes del cuerpo normalmente cubiertas por ropa, se efectuará en un lugar reservado y fuera de la vista de terceros. Se dejará constancia.

Este artículo permite la práctica de un registro corporal externo y superficial a la persona, que puede consistir, incluso, en su desnudo, parcial o integral, y no exige que el resultado de la diligencia en cuestión se ponga en conocimiento del Ministerio Fiscal ni del juez, bastando para su validez con dejar constancia escrita de la misma, de sus causas y de la identidad del agente que la adoptó.

En el recurso se alega la vulneración del artículo 10.1 CE (derecho a la dignidad de la persona), el artículo $15 \mathrm{CE}$ (derecho a la integridad física y moral) y el artículo $18 \mathrm{CE}$ (derecho a la intimidad personal) al permitir el registro corporal externo y superficial que, incluso, puede consistir en un desnudo total o parcial, sin que el legislador exija la concurrencia de razones de urgencia y necesidad y sin establecer los requisitos y garantías, exigidos por la Constitución y plasmados en la doctrina jurisprudencial del Tribunal Constitucional.

El Tribunal Constitucional fundamenta su resolución sobre la conformidad constitucional de la regulación legal apoyándose en la vasta jurisprudencia recaída sobre esta materia a raíz de analizar determinadas medidas de seguridad que impactan en los derechos fundamentales. Así, recuerda que las inspecciones y registros corporales (objeto de la norma recurrida) "consisten en cualquier género de recono- 
cimiento del cuerpo humano, bien sea para la determinación del imputado (diligencias de reconocimiento en rueda, exámenes dactiloscópicos o antropomórficos, etc.) o de circunstancias relativas a la comisión del hecho punible (electrocardiogramas, exámenes ginecológicos, etc.) o para el descubrimiento del objeto del delito (inspecciones anales o vaginales, etc.)", pudiendo "verse afectado el derecho fundamental a la intimidad corporal (art. 18.1 $1^{\circ} \mathrm{CE}$ ) si recaen sobre partes íntimas del cuerpo, como fue el caso examinado en la STC 37/1989 (examen ginecológico), o inciden en la privacidad" (STC 207/1996, FJ $2^{\circ}$ a). Son diferentes a las denominadas "intervenciones corporales" "consistentes en la extracción del cuerpo de determinados elementos externos o internos para ser sometidos a informe pericial (análisis de sangre, orina, pelos, uñas, biopsias, etc.) o en su exposición a radiaciones (rayos X, TAC, resonancias magnéticas, etc.), con objeto también de averiguar determinadas circunstancias relativas a la comisión del hecho punible", pues en estos casos "el derecho que se verá por regla general afectado es el derecho a la integridad física (art. $15 \mathrm{CE}$ ), en tanto implican una lesión o menoscabo del cuerpo, siquiera sea de su apariencia externa" (STC 207/1996, FJ 2º b).

Así lo anterior, los registros o inspecciones corporales suponen una intervención en el derecho a la intimidad, ya como intimidad corporal o como intimidad personal. En la jurisprudencia constitucional se ha abordado el elemento del pudor o recato personal, entendiendo que no son intromisiones forzadas en la intimidad aquellas actuaciones que, por las partes del cuerpo sobre las que se operan o por los instrumentos mediante los que se realizan, "no constituyen, según un sano criterio, violación del pudor o del recato de la persona" (STC 57/1994, de 28 de febrero, FJ 5 ${ }^{\circ}$ b). Siguiendo esta interpretación se considera que "resulta indudable que el desnudo integral de la persona incide en el ámbito de su intimidad corporal constitucionalmente protegido, según el criterio social dominante en nuestra cultura" (STC 196/2006, de 3 de julio, FJ $5^{\circ}$ ) incluso en una relación de sujeción especial desarrollada en el ámbito penitenciario (STC 57/1994, FJ $7^{\circ}$ ).

El carácter limitado del derecho supone que pueda ser intervenido cumpliendo los requisitos que proporcionan una justificación constitucional objetiva y razonable a dicha injerencia:

a) la existencia de un fin constitucionalmente legítimo;

b) que exista una previsión legal específica de la medida limitativa del derecho, no pudiendo ser autorizada la misma solo por la vía reglamentaria (principio de legalidad);

c) que, como regla general, se acuerde mediante resolución judicial motivada sin que, en determinados casos, por acreditadas razones de urgencia y necesidad, y con la conveniente habilitación legislativa, tales actuaciones pudieran ser dispuestas por la policía judicial; y 
d) que sea idónea, necesaria y proporcionada para la consecución del fin perseguido (STC 206/2007, de 24 de septiembre, FJ 6º ; con cita de las SSTC 207/1996, de 16 de diciembre, FJ $4^{\circ} ; 234 / 1997$, de 18 de diciembre, FJ 9o; 70/2002, de 3 de abril, FJ $10^{\circ}$, y 25/2005, de 14 de febrero, FJ $6^{\circ}$ ).

Para el Tribunal Constitucional, siguiendo las previsiones legales, estas intervenciones responden a "la preservación de la seguridad y la convivencia ciudadanas" (art. 3 c); garantizando el buen desarrollo y eficacia de la acción policial, en conexión con la "prevención de la comisión de delitos o infracciones administrativas" (art. 3 h), en línea con el art. 282 de la Ley de Enjuiciamiento Criminal que establece que la policía judicial tiene la obligación de investigar los delitos y practicar "las diligencias necesarias para comprobarlos y descubrir a los delincuentes, y recoger todos los efectos, instrumentos o pruebas del delito de cuya desaparición hubiere peligro, poniéndolos a disposición de la autoridad judicial".

En este orden de cosas, el precepto impugnado se pone en relación con el art. $18.1^{\circ}$ de la LOPSC, relacionado con los efectos y objetos relevantes para el cumplimiento de las funciones policiales de indagación e investigación porque prevé que los agentes de la autoridad podrán practicar en las personas, y también en bienes y vehículos, las comprobaciones necesarias para impedir que en las vías, lugares y establecimientos públicos "se porten o utilicen ilegalmente armas, explosivos, sustancias peligrosas u otros objetos, instrumentos o medios que generen un riesgo potencialmente grave para las personas, susceptibles de ser utilizados para la comisión de un delito o alterar la seguridad ciudadana”. Además de que el art. $16.1^{\circ}$ precisa los hechos o circunstancias que conducen a la intervención policial como aquellos necesarios para la indagación y prevención del delito o sanción de las infracciones; que, en todo caso, se justificará "en la existencia de una amenaza concreta o de un comportamiento objetivamente peligroso que, razonablemente, sea susceptible de provocar un perjuicio real para la seguridad ciudadana y, en concreto, atentar contra los derechos y libertades individuales y colectivos o alterar el normal funcionamiento de las instituciones públicas" (art. $4.3^{\circ}$ ).

Así lo anterior, el Tribunal Constitucional realiza una interpretación sistemática que le lleva a confirmar la constitucionalidad de la práctica de registros corporales externos y superficiales, que incluso puedan conllevar el desnudo parcial, cuando se cumplen los requisitos exigidos que determinan la idoneidad y necesidad de la medida para la consecución de la finalidad legalmente prevista. Además, para mayor garantía del derecho afectado, salvo en situaciones de urgencia o existencia de un grave e inminente riesgo para los agentes, el registro o cacheo será practicado por agente del mismo sexo y en lugar reservado y fuera de la vista de terceros. Y, a mayor abundamiento, el registro corporal será realizado, en todo caso, con respeto a los principios de injerencia mínima, de menor perjuicio a la intimidad y dignidad de la persona afectada, y de 
idoneidad, necesidad y proporcionalidad, igualdad de trato y no discriminación (arts. $20.3^{\circ}$ y $4^{\circ}$ y $16.1^{\circ}$ LOPSC).

\section{EL RÉGIMEN SANCIONADOR PREVISTO EN LA LEY ORGÁNICA DE PROTECCIÓN DE LA SEGURIDAD CIUDADANA}

Uno de los puntos calientes de la Ley y objeto del recurso es su régimen sancionador en cuanto que se incrementan las infracciones y se aumentan las sanciones, afectando especialmente al derecho de reunión y manifestación en lugares públicos. En este orden de cosas, se recurren por inconstitucionales los arts. $36.2^{\circ}$ y $37.1^{\circ}$ en relación con el $30.3^{\circ}, 37.3^{\circ}$ y $37.7^{\circ}$, por vulneración del art. 21 CE.

La regulación constitucional del ejercicio de este derecho de participación (art. $21.2^{\circ} \mathrm{CE}$ ) establece como elemento de delimitación de su contenido constitucionalmente protegido la comunicación previa a la autoridad competente cuando la reunión se celebre en un lugar público. No se trata, pues, de una restricción del derecho ni de un obstáculo para su realización sino de un elemento que viene a delimitar su correcto ejercicio para armonizar los derechos y bienes con los que podría colisionar. Dicho en otras palabras, ante el incumplimiento estamos ante una actuación carente de protección constitucional para la que no cabe solicitar amparo (STC 36/1982, de 16 de junio, FJ $6^{\circ}$; STC 42/2000, de 14 de febrero, FJ $2^{\circ}$ ). En la misma línea el Tribunal Europeo de Derechos Humanos.

Así, resulta evidente la diferencia entre comunicación previa y la posibilidad de prohibir la celebración de reuniones y manifestaciones en lugares de tránsito público, pues en el segundo supuesto la prohibición restringe el derecho, pero siendo una excepción que solo cabe cuando existan "razones fundadas" de alteración del orden público con peligro para personas y bienes. Es reiterada la jurisprudencia que concreta las razones fundadas, quedando descartada toda mera sospecha o posibilidad de que la concentración produzca dicha alteración (STC 66/1995, de 8 de mayo, FJ 3º), o que interpreta el desorden material como aquel "que impide el normal desarrollo de la convivencia ciudadana en aspectos que afectan a la integridad física o moral de personas o a la integridad de bienes públicos o privados" (STC 66/1995, de 8 de mayo, $\mathrm{FJ} 3^{\circ}$ ).

A mayor abundamiento se establecen garantías del derecho relacionadas con la decisión que adopte la autoridad competente tras la preceptiva ponderación: la motivación de la resolución, fundamentación y justificación de la medida como necesaria (SSTC 66/1995, de 8 de mayo, FJ 3º y 42/2000, de 14 de febrero, FJ 2º. Si bien, en todo caso, antes de prohibir el ejercicio del derecho fundamental, deberá proponer alternativas en aplicación del principio de proporcionalidad, optando, si fuera posible, por medidas menos gravosas como modificaciones de fecha, lugar o duración (STC $42 / 2000$, de 14 de febrero, FJ $2^{\circ}$ ), pues la interpretación sistemática de los preceptos 
constitucionales conduce a la aplicación del principio favor libertatis (STC 66/1995, de 8 de mayo, $\mathrm{FJ}^{\circ}$ ).

No obstante lo anterior, podría prohibirse una reunión o manifestación si durante su celebración se vulneran los límites establecidos o se produce el incumplimiento del deber de comunicación previa. En todo caso, dicha posibilidad, por resultar tan gravosa para el ejercicio del derecho, será resultado de las circunstancias concurrentes y tras su análisis por la autoridad competente (STC 42/2000, FJ $2^{\circ}$ ). Obviamente, teniendo presente la diferencia entre manifestaciones no comunicadas (manifestaciones ilegales) frente a manifestaciones prohibidas (STEDH Kudrevićius y otros c. Lituania, \149), pues las consecuencias jurídicas difieren, y sin perder de vista que desde el Tribunal Europeo de Derechos Humanos se pide a las autoridades nacionales cierto grado de tolerancia atendiendo a las circunstancias específicas que concurren en cada caso (STEDH Yllmaz Yuldiz y otros c. Turquía, de 14 de octubre de 2014).

Dicho lo anterior, no parece que la equiparación que se hace en el art. $35.1^{\circ}$, "son infracciones muy graves las reuniones o manifestaciones no comunicadas o prohibidas en infraestructuras o instalaciones en las que se prestan servicios básicos para la comunidad o en sus inmediaciones", resulte respetuosa con el principio de proporcionalidad que debe presidir el régimen sancionador.

La Ley Orgánica 5/1983, de desarrollo del derecho de reunión, establece claramente los efectos de la falta de comunicación o incumplimiento del deber constitucionalmente establecido y los efectos de la comprobación por la autoridad gubernativa de la concurrencia de razones fundadas de que pudieran producirse alteraciones del orden público, con peligro para personas o bienes. Solo será en este supuesto cuando se podría prohibir la reunión o manifestación si no fuera posible proponer la modificación de la fecha, lugar, duración o itinerario de la reunión o manifestación. Por tanto, a quien suscribe estas páginas, le parece desproporcionado imponer la misma sanción para dos conductas que son diferentes y que, evidentemente, producen efectos distintos para la seguridad ciudadana.

Se impugna la sanción de las reuniones y manifestaciones en lugares concretos como las sedes del Congreso de los Diputados, Senado o asambleas legislativas autonómicas por lesionar la seguridad ciudadana (art. $36.2^{\circ}$ ), bien por incumplimiento de los requisitos legales o de las decisiones adoptadas por la autoridad competente (art. 37.1 $3^{\circ}$ y $7^{\circ}$ ), y también el art. $30.3^{\circ}$ que amplía el ámbito de responsabilidad de los sujetos, definiendo quiénes se consideran organizadores o promotores de reuniones en lugares de tránsito público o manifestaciones.

Los recurrentes argumentan que se produce una afectación del contenido esencial (art. 53.1 ${ }^{\circ} \mathrm{CE}$ ) del derecho del art. $21 \mathrm{CE}$, lo que, como es sabido, convierte en inconstitucional la cláusula de intervención toda vez que dicha exigencia de responsabilidad produce un efecto disuasorio o desalentador en la participación ciudadana, es decir, disuade del ejercicio del derecho por temor a incurrir en dicha responsabilidad. 
En la impugnación del art. $36.2^{\circ}$ se alega que dicha restricción resulta injustificada, puesto que la finalidad de garantizar la independencia e inviolabilidad de la actividad parlamentaria, según el art. $77 \mathrm{CE}$, solo tiene sentido cuando las cámaras legislativas estén reunidas; y porque su aplicación no exige el cumplimiento de los límites previstos específicamente en el art. $21.2^{\circ} \mathrm{CE}$, ya que la simple ausencia de la previa comunicación no supone la prohibición.

Sin embargo, para el Tribunal Constitucional en la sentencia objeto de análisis, las sedes parlamentarias revisten una doble transcendencia que merece protección jurídica. Por un lado, albergan el desarrollo efectivo de las funciones representativas por medio del funcionamiento del órgano legislativo en sus distintas formas y composiciones; y, por otro, son las depositarias de la soberanía popular, de modo que, aun estando inactivas, representan institucionalmente la voluntad popular, convirtiéndose en un símbolo constitucional.

Así, en atención a esa doble significación, el Tribunal Constitucional declara que el precepto impugnado sanciona la perturbación grave de la seguridad ciudadana ocasionada por la celebración de reuniones o manifestaciones ante las instituciones parlamentarias que impidan el normal funcionamiento del órgano parlamentario, o produzcan una desconsideración del símbolo que encarnan. Por consiguiente, para el Tribunal Constitucional se trata de una medida idónea a los fines establecidos, esto es, la protección de la significación institucional de los órganos parlamentarios y su valor simbólico plenamente vigente aun cuando no estén reunidos.

La infracción tipificada en el art. $37.1^{\circ}$ como leve solamente podrá ser cometida, no por quienes simplemente participen en esas reuniones o manifestaciones no comunicadas, sino por los que tengan la consideración de promotores y organizadores. Pero, además, no es suficiente con tener objetivamente esta condición o que la misma se pueda deducir razonablemente de alguno de los hechos que recoge la norma u otros de similar naturaleza, ya que además se han de cumplir las exigencias derivadas del principio de culpabilidad.

Ciertamente, nos parece asumible la posición del Tribunal Constitucional en orden a garantizar la significación institucional y representativa de las cámaras legislativas, pero, sin embargo, la norma debería ser más clara y más precisa.

Por lo que respecta al art. $37.3^{\circ}$ LOPSC, confirma su constitucionalidad siempre que este precepto se interprete del siguiente modo: "El incumplimiento de las restricciones de circulación peatonal o itinerario con ocasión de un acto público, reunión o manifestación, cuando provoquen alteraciones menores en el normal desarrollo de los mismos", lo mismo que el art. $37.7^{\circ}$ que tipifica como infracción leve "La ocupación de cualquier inmueble, vivienda o edificio ajenos, o la permanencia en ellos, en ambos casos contra la voluntad de su propietario, arrendatario o titular de otro derecho sobre el mismo, cuando no sean constitutivas de infracción penal”. 
El régimen sancionador se ve aumentado con la tipificación de infracciones vinculadas al uso no autorizado de imágenes o datos personales o profesionales de las autoridades o miembros de las Fuerzas y Cuerpos de Seguridad (art. 36.23\%). Este precepto considera como infracción grave "el uso no autorizado de imágenes o datos personales o profesionales de autoridades o miembros de las Fuerzas y Cuerpos de Seguridad que pueda poner en peligro la seguridad personal o familiar de los agentes, de las instalaciones protegidas o en riesgo el éxito de una operación, con respeto al derecho fundamental a la información", sin olvidar que, de conformidad con el artículo 19, se prevé que:
... la aprehensión durante las diligencias de identificación, registro y comprobación de armas, drogas tóxicas, estupefacientes, sustancias psicotrópicas u otros efectos procedentes de un delito o infracción administrativa se hará constar en el acta correspondiente, que habrá de ser firmada por el interesado; si éste se negara a firmarla, se dejará constancia expresa de su negativa. El acta que se extienda gozará de presunción de veracidad de los hechos en ella consignados, salvo prueba en contrario.

A nuestro juicio, la regulación de estas conductas presenta dificultades evidentes. Por una parte, la necesidad de proteger en el ejercicio de sus funciones constitucionales a quienes ejercen autoridad. De hecho, el precepto se justifica en la protección de la seguridad personal o familiar de los agentes, así como la integridad de las instalaciones protegidas o el éxito de una operación policial, siendo fines protegidos en la ley en el citado art. 3, letras a, d, g y h $\mathrm{h}^{4}$. Y, por otra, la garantía del ejercicio de los derechos de la ciudadanía y el cumplimiento del principio básico de control del ejercicio de poder y rendición de cuentas. Así pues, la captación de imágenes de los miembros de las Fuerzas y Cuerpos de Seguridad debe ser analizada desde esta perspectiva, la regla en democracia es el control del ejercicio de las funciones públicas que debe ponderarse en cada caso concreto atendiendo a las circunstancias concurrentes.

La Ley Orgánica 1/1982, de 5 de mayo, de protección civil del derecho al honor, a la intimidad personal y familiar y a la propia imagen, dispone que:

\footnotetext{
... en particular, el derecho a la propia imagen no impedirá: a) Su captación, reproducción o publicación por cualquier medio, cuando se trate de personas que
}

4 El libre ejercicio de derechos y libertades garantizados en el ordenamiento; el respeto a la paz y seguridad ciudadana en el ejercicio de los derechos; seguridad personal y familiar de los agentes; normalidad en la prestación de servicios públicos esenciales; prevención de delitos e infracciones. 
ejerzan un cargo público o una profesión de notoriedad o proyección pública y la imagen se capte durante un acto público o en lugares abiertos al público (art. $8.2^{\circ}$ ).

Asimismo, el propio Tribunal Constitucional en la STC 72/2007, de 16 de abril, a propósito de la publicación de una foto en la que se identificó a una agente de la policía local que participó en un desahucio, estimó que se encuadraba en el supuesto regulado en el art. $8.2^{\circ}$ a) de la Ley antes citada. El Alto Tribunal estima que "el examen de la fotografía y del texto que la acompaña pone de manifiesto que estamos ante un documento que reproduce la imagen de una persona en el ejercicio de un cargo público" y "que la fotografía en cuestión fue captada con motivo de un acto", "en un lugar público" además de que "la información que se transmite por el periódico es veraz y tiene evidente trascendencia pública".

Por otra parte, resulta fundamental analizar esta conducta desde el régimen jurídico de las libertades de información que resultan afectadas, a juicio de los recurrentes, por una restricción previa y desproporcionada. Por tanto, debe relacionarse con la modalidad de censura previa (prohibida sin excepción en el art. 20.2 CE) y con el art. $20.5^{\circ} \mathrm{CE}$, que contempla el secuestro de publicaciones en virtud de resolución judicial. En su argumentación el Tribunal Constitucional trae a colación la STC 34/2010, de 19 de julio, FJ 5º en la que se declaró la constitucionalidad de la adopción por órganos judiciales de medidas cautelares que, constituyan o no secuestro judicial en sentido estricto, impliquen restricciones previas a la difusión de mensajes con el objeto de atajar el riesgo de lesión de otros bienes o derechos constitucionales.

No obstante, no compartimos la posición del Pleno del Tribunal Constitucional porque el art. $19.2^{\circ}$ de la LOPSC, en relación con el $36.23^{\circ}$, vulnera la reserva a los órganos judiciales de la autorización "del secuestro de publicaciones, grabaciones y otros medios de información" (art. 20.5 $\mathrm{CE}$ ), al atribuir esta potestad a la Administración. Y así se ha interpretado en su jurisprudencia, cuando recordaba que "la propia Constitución legitima el secuestro de publicaciones, grabaciones y otros medios de información, aunque sólo podrá acordarse en virtud de una resolución judicial (art. $20.5^{\circ} \mathrm{CE}$ ), prohibiendo por tanto implícitamente la existencia del llamado secuestro administrativo" (STC 187/1999, de 25 de octubre, FJ $6^{\circ}$ ).

Se trata, pues, de realizar una correcta ponderación cuando se realiza una difusión no autorizada, que pueda o haya podido causar una situación de peligro para la seguridad de un agente, entre derecho de información y la garantía de la seguridad y otros derechos fundamentales de los agentes grabados. Las libertades de expresión e información tienen un alcance delimitado y encuentran limitaciones en su ejercicio dadas por la necesidad de garantizar los derechos de los demás, especialmente los derechos de la personalidad, la privacidad y protección de datos personales, así como otros intereses públicos como es la seguridad ciudadana. 
Y la sentencia declarará que el art. $36.23^{\circ}$ no es inconstitucional siempre que se interprete del siguiente modo el término "uso": debe interpretarse en el sentido de que para que pueda apreciarse infracción grave es necesaria la publicación o difusión ilícita, no bastando la mera captación no seguida de publicación o difusión; y el término "imágenes o datos personales o profesionales" comprende también las relativas a la vida privada, elemento este que deberá tomarse en cuenta para determinar si prevalece o no el derecho a la información.

Se declara la inconstitucionalidad del inciso "no autorizado" de dicho precepto por resultar contraria a la interdicción de censura previa contenida en el art. 20.2 ${ }^{\circ} \mathrm{CE}$.

\section{IMPUGNACIÓN DEL RÉGIMEN ESPECIAL PARA CEUTA Y MELILLA DE RECHAZO EN LA FRONTERA DE LOS EXTRANJEROS QUE INTENTEN ENTRAR ILEGALMENTE}

Como a nadie se le oculta, otro de los contenidos polémicos son las conocidas como "devoluciones en caliente" o "devoluciones inmediatas" que se aplica en los territorios de Ceuta y Melilla. La disposición final primera de la Ley Orgánica 4/2015, añade una nueva disposición adicional décima a la Ley Orgánica 4/2000, de 11 de enero, sobre derechos y libertades de los extranjeros en España y su integración social, con la siguiente redacción:

\footnotetext{
1. Los extranjeros que sean detectados en la línea fronteriza de la demarcación territorial de Ceuta o Melilla mientras intentan superar los elementos de contención fronterizos para cruzar irregularmente la frontera podrán ser rechazados a fin de impedir su entrada ilegal en España. 2. En todo caso, el rechazo se realizará respetando la normativa internacional de derechos humanos y de protección internacional de la que España es parte. 3. Las solicitudes de protección internacional se formalizarán en los lugares habilitados al efecto en los pasos fronterizos y se tramitarán conforme a lo establecido en la normativa en materia de protección internacional.
}

Sin embargo, entendemos que la norma que se introduce en la Ley de Extranjería, sí crea un nuevo procedimiento de devolución de los extranjeros que entran ilegalmente en España que no cuenta con las garantías judiciales previstas en el artículo

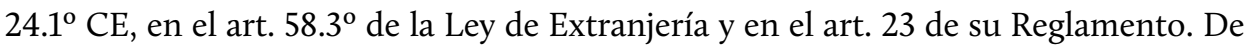
acuerdo con estos preceptos, toda persona que pretenda entrar irregularmente en el país, incluidos aquellos que sean interceptados en la frontera o en sus inmediaciones, debería ser objeto de un procedimiento de devolución, con las garantías jurídicas previstas de forma específica para los procedimientos de extranjería fijados en el art. 20.2 de la Ley de Extranjería. 
El Alto Tribunal concluye que resulta conforme a la Constitución la disposición final primera de la LOPSC siempre que se aplique a entradas individualizadas, sometidas a control judicial y se cumplan las obligaciones internacionales; teniendo especial consideración a las personas especialmente vulnerables (menores de edad, embarazadas o personas de edad avanzada). El Tribunal Constitucional confirma la disposición por no ser contraria a la doctrina internacional sobre derechos humanos, en cuanto que el Tribunal de Estrasburgo avaló dichas actuaciones:

\section{[el] rechazo en frontera es una actuación material de carácter coactivo, que tiene por finalidad restablecer inmediatamente la legalidad transgredida por el intento por parte de las personas extranjeras de cruzar irregularmente esa concreta frontera terrestre. La actuación material (será constitucional), sin perjuicio del control judicial que proceda realizarse en virtud de las acciones y recursos que interponga, en cada caso concreto, la persona extranjera ${ }^{5}$.}

Por otra parte, entiende que la disposición adicional décima de la Ley Orgánica sobre derechos y libertades de los extranjeros en España en nada excepciona el régimen jurídico previsto en la Ley 12/2009, de 30 de octubre, reguladora del derecho de asilo y de la protección subsidiaria de asilo, al limitarse a indicar dónde se han de formalizar las solicitudes - puestos fronterizos de Ceuta y Melilla-, y que deben existir los medios que permitan acceder a un procedimiento de entrada legal al territorio español.

Como se ha dicho la sentencia tuvo dos votos en contra y se formuló un voto particular discrepante. El magistrado Cándido Conde-Pumpido incidió en la necesidad del cumplimiento del punto 3 de la disposición final, que prevé que "las solicitudes de protección internacional se formalizarán en los lugares habilitados al efecto en los pasos fronterizos y se tramitarán conforme a lo establecido en la normativa en materia de protección internacional”.

\section{CONCLUSIÓN}

Garantizar la seguridad puede justificar la creación de límites de los derechos que, en ningún caso, son categorías absolutas o ilimitadas en una sociedad de convivencia democrática. Ahora bien, toda medida que suponga una restricción de derechos y libertades requiere una interpretación y aplicación restrictiva, de modo que no se invierta la relación entre la norma -la libertad- y la excepción -la limitación-. Este

5 Así, se concluye que esta decisión resulta conforme a la doctrina de la sentencia en la que el Tribunal Europeo de Derechos Humanos dio la razón al Estado español en relación con la expulsión inmediata de dos inmigrantes, de Mali y Costa de Marfil, que saltaron la valla fronteriza de Melilla en agosto de 2014. 
principio parece debilitarse en el régimen sancionador contemplado en la Ley Orgánica de Protección de la Seguridad Ciudadana, si bien el Tribunal Constitucional prácticamente ha confirmado en su totalidad la adecuación constitucional de los preceptos impugnados.

Bien es cierto que puede tener cabida en la Constitución una intervención pública en los derechos, más o menos intensa, si supera el test o juicio de proporcionalidad y, obviamente, no afecta al contenido esencial de estas categorías jurídicas. Pero no es menos cierto que, desde una perspectiva más proactiva hacia los derechos y libertades y menos apegada a la seguridad o al papel sancionador del Estado, la solución legislativa podría haber sido otra, en la línea demandada por los organismos internacionales, organizaciones defensoras de los derechos humanos, movimientos sociales o determinadas fuerzas políticas. 